\title{
Pregled djelovanja Pulmološkog društva Hrvatske udruge medicinskih sestara od 1974. do 2021. godine
}

\section{A Review of Activities of the Pulmonology Society of the Croatian Nurses Association 1974-2021}

\author{
Slađana Režić, Tatjana Munko² \\ ${ }^{1}$ KBC Zagreb, Odjel za osiguranje i unapređenje kvalitete zdravstvene zaštite, Kišpatićeva 12, 10000 Zagreb, Hrvatska / UHC Zagreb, Department for \\ Health Care Quality Assurance and Improvement, Kišpatićeva 12, 10000 Zagreb, Croatia \\ ${ }^{2}$ Specijalna bolnica za plućne bolesti, Rockefellerova 3, 10000 Zagreb, Hrvatska / Special hospital for lung diseases, Rockefellerova 3, 10000 Zagreb, \\ Croatia
}

\section{Sažetak}

Uvod: Profesionalno udruživanje medicinskih sestra na našim prostorima kasnih 1960-ih obilježilo je osnivanje sekcija koje se profiliraju prema određenim sestrinskim specijalnostima. Među njima bila je i pneumoftiziološka (pulmološka) sekcija. Današnji nasljednici tih sekcija jesu društva Hrvatske udruge medicinskih sestara (HUMS). Sekcije/društva čine jezgru profesionalne i stručne komunikacije, no o njihovu radu postoji vrlo malo publikacija. Stoga je cilj ovog rada prikazati djelovanje Pulmološkog društva HUMS-a u razdoblju od osnivanja 1974. do 2021. godine.

Metode: Podaci prikazani u radu prikupljeni su iz zapisnika skupština i izvještaja o radu Pneumoftiziološke sekcije Društva medicinskih sestara i medicinskih tehničara SR Hrvatske / Pulmološkog društva HUMS-a. Vrijedan izvor podataka za razdoblje od 1975. do 1989. godine bio je Bilten koji je izdavala sekcija. Dodatno su korišteni zbornici radova s održanih skupova.

Rezultati: Pneumoftiziološka sekcija Društva medicinskih sestara i medicinskih tehničara SR Hrvatske osnovana je 22. studenog 1974. godine s ciljem stručnog usavršavanja članova i rješavanja stručnih problema. Danas djeluje pod nazivom Pulmološko društvo HUMS-a. Društvo je organiziralo četrdeset dva stručna skupa, brojne seminare, radionice, studijske posjete i javnozdravstvene aktivnosti. Od 1975. do 1989. godine izdana su dvadeset tri broja Biltena - stručnog glasila Pneumoftiziološke sekcije, u kojem su objavljivani stručni radovi te planovi i izvještaji o radu. Od 1998. do 2008. godine objavljena su četiri zbornika radova sa stručnih skupova. Članovi Pulmološkog društva objavljivali su stručne radove i u drugim publikacijama. Djelatnost Pulmološkog društva ostvarivana je u suradnji s drugim stručnim društvima medicinskih sestara i liječnika, zdravstvenim ustanovama i tijelima državne uprave.

Zaključak: Pulmološko društvo HUMS-a kontinuirano djeluje četrdeset sedam godina. Sukladno ciljevima osnivanja, ključna djelatnost bila mu je organizacija raznih oblika trajnog stručnog usavršavanja medicinskih sestara. U najranijim godinama djelovanja Pulmološko društvo objavljivalo je stručno glasilo Bilten, a kasnije zbornike radova sa stručnih skupova. Cjelokupnu djelatnost Pulmološkog društva obilježila je suradnja s drugim stručnim društvima i organizacijama.

Ključne riječi: Pneumoftiziološka sekcija Društva medicinskih sestara i medicinskih tehničara SR Hrvatske, Pulmološko društvo medicinskih sestara, Hrvatska udruga medicinskih sestara, povijest sestrinstva

\begin{abstract}
Introduction: The professional association of nurses in Croatia and Ex-Yugoslavia during the late 1960s marked the establishment of sections profiled according to certain nursing specialties. One of them was the section of pneumophthisiology (pulmonology). Current successors of these Sections are the Societies of the CNA. Sections/societies make up the core of professional and expert communication, but there are very few publications on their work. Therefore, the aim of this paper is to highlight the activities of the Pulmonology society of the CNA since its inception in 1974 until 2021.
\end{abstract}

Methods: The data presented in the paper was collected from the minutes of assemblies and work reports of the Pneumophthisiology Section of the Nurses' Society of the Socialist Republic of Croatia / the Pulmonology Society of the CNA. A valuable source of information from the time between 1975 and 1989 was the Bulletin that was published by the Section. Additionally, conference proceedings from conferences held were also used.

Results: The Pneumophthisiology section of the Society of Nurses of the Socialist Republic of Croatia was founded on 22 November 1974 with the aim of providing professional education to members and solving professional issues. Today it operates as the Pulmonology Society of the Croatian Nurses' Association. It organized forty-two professional conferences, numerous seminars, workshops, study visits and public health activities. From 1975 to 1989, twenty-three issues of the professional journal of the Pneumophthisiology section, the so called "Bulletin", were published. The Bulletin published papers, work plans, and work reports. From 1998 to 2008 four conference proceedings from professional conferences were published. Members of the Pulmonology Society also published papers in other publications. The activities of the Pulmonology Society were carried out in cooperation with other professional societies of nurses and doctors, as well as health care organizations and state administration bodies.

Conclusion: The Pulmonology Society of the CNA has been continuously active for forty-seven years. In accordance with the aims of its establishment, its key activity was the organization of various forms of professional education for nurses. In the earliest years of its activity, the Pulmonology Society published its professional journal, the "Bulletin", and later also conference proceedings from professional conferences. The hallmark of the Pulmonology Society's entire activity was cooperation with other professional societies and organizations.

Keywords: Pneumophthisiology Section of the Nurses' Society of the Socialist Republic of Croatia, the Pulmonology Society of Nurses, the Croatian Nurses' Association, history of nursing 


\section{Uvod}

Profesionalno udruživanje medicinskih sestra na našim prostorima kasnih 1960-ih obilježilo je osnivanje sekcija u sklopu Društva medicinskih sestara i medicinskih tehničara SR Hrvatske koje se profiliraju prema određenim sestrinskim specijalnostima. Među njima, bila je i pneumoftiziološka (pulmološka) sekcija. Današnji nasljednici tih su sekcija društva Hrvatske udruge medicinskih sestara (HUMS). Sekcije/društva čine jezgru profesionalne i stručne komunikacije, no o njihovu radu postoji vrlo malo publikacija. Stoga je u radu prikazano djelovanje Pulmološkog društva HUMS-a u razdoblju od osnivanja 1974. do 2021. godine. Podaci prikazani u radu prikupljeni su iz zapisnika skupština i izvještaja o radu Pneumoftiziološke sekcije Društva medicinskih sestara i medicinskih tehničara SR Hrvatske / Pulmološkog društva HUMS-a. Vrijedan izvor podataka za razdoblje od 1975. do 1989. godine bio je Bilten koji je izdavala sekcija. Dodatno su korišteni zbornici radova s održanih skupova.

\section{Osnutak Pneumoftiziološke sekcije}

Pneumoftiziološka sekcija Društva medicinskih sestara i medicinskih tehničara SR Hrvatske osnovana je 22. studenog 1974. godine i danas djeluje pod imenom Pulmološko društvo Hrvatske udruge medicinskih sestara. Osnivačka skupština održana je uz potporu Zbora liječnika Hrvatske, Zavoda za zaštitu zdravlja Hrvatske te Odjela za proučavanje i suzbijanje plućnih bolesti i tuberkuloze. Na osnivačkoj skupštini prisustvovale su 122 medicinske sestre / medicinska tehničara. Za prvu predsjednicu izabrana je Katarina Krvavica na čiju inicijativu je i pokrenuta ideja osnivanja sekcije. Osnovni ciljevi sekcije bili su: stručno usavršavanje članova, proučavanje stručnih problema i prijedloga za njihovo rješavanje, etičko uzdizanje članova, suradnja s drugim stručnim sekcijama i organizacijama, te organizacija simpozija i stručnih seminara. Na osnivačkoj skupštini, održano je i prvo stručno savjetovanje [1]. Po uzoru na Pneumoftiziološku sekciju osnivaju se sekcije i u drugim republikama Jugoslavije. Tako su osnovane sekcije u Sloveniji, Srbiji, Bosni i Hercegovini, Makedoniji i Crnoj Gori.

\section{Predsjednice Pneumoftiziološke sekcije / Pulmološkog društva HUMS-a}

Sekcija je u počecima svoje predsjednice birala na mandat od dvije godine. Dogovoreno je da se naizmjenično biraju predsjednice iz bolničke, odnosno dispanzersko-patronažne službe [1]. Na taj se način željela osnažiti veza između bolničke i dispanzerske službe.

Plan rada koji je predlagala predsjednica nakon odobrenja Izvršnog odbora bio je objavljen u Biltenu, službenom glasilu Pneumoftiziološke sekcije. Predsjednica je po završetku svog mandata podnosila izvješće o radu sekcije koje je također objavljivano u Biltenu. Nakon isteka mandata, predsjednice u pravilu nastavljaju svoj rad i doprinose razvoju i napretku Društva putem aktivnosti u Izvršnom odboru, uredništvu Biltena ili pisanjem stručnih radova. Od 1992.

\section{Introduction}

The professional association of nurses in Croatia and ExYugoslavia during the late 1960s marked the establishment of sections in the Society of Nurses of the Socialist Republic of Croatia, profiled according to certain nursing specialties. One of them was the section of pneumophthisiology (pulmonology). Current successors of these Sections are the Societies of the CNA. Sections/societies make up the core of professional and expert communication, but there are very few publications on their work. The work therefore highlighted the activities of the Pulmonology society of the CNA between 1974 and 2021. The data presented in the paper was collected from the minutes of assemblies and work reports of the Pneumophthisiology Section of the Nurses' Society of the Socialist Republic of Croatia / The Pulmonology Society of the CNA. A valuable source of information from the time between 1975 and 1989 was the Bulletin that was published by the Section. Additionally, conference proceedings from conferences held were also used.

\section{The establishment of the Pneumophthisiology Section}

The Pneumophthisiology section of the Society of Nurses of the Socialist Republic of Croatia was founded on 22 November 1974 and today operates as the Pulmonology Society of the Croatian Nurses' Association (CNA/HUMS). The founding assembly was held with the support of the Croatian Physicians' Association, the Croatian Institute for Health Protection and the Department for the Study and Prevention of Lung Diseases and Tuberculosis. 122 nurses attended the founding assembly. Katarina Krvavica, the initiator of the Section's establishment, was elected as the first president. The basic goals of the Section were as follows: professional education of members, the study of professional issues and proposals for their solving, ethical elevation of members, cooperation with other professional sections and organizations, as well as the organization of conferences and professional seminars. At the founding assembly, the first professional conference was held [1]. Following the example of the Pneumophthisiology Section of Croatia, Sections were established in other federal republics of Yugoslavia. Thus, sections were established in Slovenia, Serbia, Bosnia-Hercegovina, Macedonia and Montenegro.

\section{Presidents of the Pneumophthisiology Section/Pulmonology Society of the CNA}

In its beginnings, the Section elected presidents for twoyear terms. It was agreed that presidents would alternate between the hospital and the community health protection services [1]. The intention was to thus forge a stronger link between the hospital and the community health protection services.

A plan of activities proposed by the president after the approval of the Executive Board would then be published in the Bulletin, the official journal of the Pneumophthisiology Section. At the end of her term, the President submitted a 
godine predsjednica se bira na mandat od četiri godine, $s$ tim da se može birati uzastopno dva puta.

Predsjednice od osnutka do danas bile su: Katarina Krvavica (1974. - 1976.); Blanka Trajkovski (1976. - 1978.); Stana Lovrić (1978. - 1980.); Đurđa Gec (1980. - 1982.); Katica Bauk (1982. - 1984.); Gordana Fučkar (1984. - 1986.); Ružica Gračak (1986. - 1988.); Katica Sever (1989. - 1992.); Ana Matajić (1992. - tri mjeseca); Anđelka Mrvelj (1992. - 1996.); Rosana Svetić Čišić (1996. - 2004.); Jasminka Ban Grahovac (2004. 2009.); Marijeta Fištrek (2009. - 2017.) i Tatjana Munko (2017. $-)$.

\section{Stručne aktivnosti Pneumoftiziološke sekcije / Pulmološkog društva HUMS-a}

Prvo stručno savjetovanje za medicinske sestre u pneumoftiziologiji održano je 1974. godine u Zagrebu. Prezentirano je 6 referata, a glavna je tema bila: Uloga medicinske sestre u socijalno-medicinskom postupku s plućnim bolesnicima. Glavni zaključak prvog savjetovanja isticao je potrebu za daljnjim školovanjem medicinskih sestara i tehničara u pneumoftiziološkoj službi. Iste godine organiziran je i posjet Bolnici za plućne bolesti i tuberkulozu Klenovnik u svrhu razmjene iskustava. Tom prigodom organiziran je $\mathrm{i}$ stručni sastanak na temu Organizacija BCG vakcinacije u Zagrebu [1].

Pneumoftiziološka sekcija organizirala je samostalno ili u suradnji s drugima (Sekcijom za patronažu i ambulatno-dispanzersku djelatnost, KB-om Merkur, KBC-om Zagreb) svečane sastanke povodom Međunarodnog dana sestrinstva [1].

U suradnji sa Zborom liječnika 1975. godine organizirano je 2. Savjetovanje Pneumoftiziološke sekcije. Ukupno je prezentirano 15 referata, a teme su se odnosile na tuberkulozu, kronične plućne bolesti te maligne tumore pluća. U Beogradu je od 28. do 30. svibnja iste godine održan 15 . Kongres pneumoftiziologa Jugoslavije i na njemu su prvi put aktivno sudjelovale i medicinske sestre Pneumoftiziološke sekcije Hrvatske sa sedam stručnih radova [2].

Od 1975. godine pa sve do Domovinskog rata sekcija je organizirala nekoliko stručnih sastanaka u bolnicama u Zagrebu, ali i izvan njega. Teme su se odnosile na tuberkulozu, kronične plućne bolesti, rak pluća i edukaciju pacijenata. Posjet Medicinskom centru Koprivnica organiziran je 1976. godine i tom prigodom održan je stručni i društveni program [3]. U listopadu 1976. u organizaciji Saveznog zavoda za zaštitu zdravlja Beograd održano je savjetovanje za medicinske sestre na kojemu su sudjelovale medicinske sestre Pneumoftiziološke sekcije s tri stručna predavanja. Treće Stručno savjetovanje održano je 1976. godine [4].

Nadalje, 4. Stručno savjetovanje održano je 1977. godine, a 5. Stručno savjetovanje 1978. godine u Stubičkim toplicama [5]. Te su se godine medicinske sestre sekcije aktivno uključile u raspravu o nacrtu Zakona o zaštiti zdravlja, posebno ističući nemogućnost daljnjeg usavršavanja i obrazovanja medicinskih sestara. Pneumoftiziološka sekcija 1979. godine podržala je i pomogla u osnivanju srodne sekcije medicinskih sestara Srbije [6]. report about the work of the Section, which was also published in the Bulletin. After the end of their term, the Presidents would, as a rule, continue their work and contribute to the development and progress of the Society through activities in the Executive Board, the editorial board of the Bulletin or by writing professional papers. Since 1992 the President had a term of four years and could be elected twice in succession.

The Presidents since establishment until now were: Katarina Krvavica (1974 - 1976); Blanka Trajkovski (1976 - 1978); Stana Lovrić (1978 - 1980); Đurđa Gec (1980 - 1982); Katica Bauk (1982 - 1984); Gordana Fučkar (1984 - 1986); Ružica Gračak (1986 - 1988); Katica Sever (1989 - 1992); Ana Matajić (1992 - three months); Anđelka Mrvelj (1992 - 1996); Rosana Svetić Čišić (1996 - 2004); Jasminka Ban Grahovac (2004 2009); Marijeta Fištrek (2009 - 2017) i Tatjana Munko (2017 $-)$.

\section{Professional activities of the Pneumophthisiology Section/Pulmonology Society of the CNA}

The first professional conference for pneumophthisiology nurses was held in Zagreb in 1974. Six reports ware presented, with the main topic being: The role of the nurse in socialmedical proceedings with lung patients. The main conclusion of the first conference emphasized the need to further the training of nurses in the pneumophthisiology service. In the same year, the Hospital for lung diseases and tuberculosis in Klenovnik was visited in order to share knowledge. On that occasion, an expert meeting was organized with the topic Organization of BCG vaccination in Zagreb [1].

The Pneumophthisiology section, independently or in cooperation with others (The Section for community health services, HC Merkur, UHC Zagreb) organized meetings on the occasion of the International Nurses Day[1].

In cooperation with the Association of Physicians, the 2nd Conference of the Pneumophthisiology Section was organized in 1975. A total of 15 papers was presented on topics relating to tuberculosis, chronic lung diseases and malignant lung tumors. The 15th Congress of Pneumophthisiologists of Yugoslavia was held in Belgrade from 28 to 30 May of the same year, and for the first time, nurses from the Pneumophthisiology Section of Croatia actively participated with seven papers.[2].

From 1975 until the War of Croatian independence, the section organized several professional conferences in hospitals in Zagreb, but also in other centers. The topics were tuberculosis, chronic lung diseases, lung cancer, patient education, etc. A visit to the Koprivnica Medical Center was organized in 1976, and on that occasion a professional and social program was held [3]. In October 1976, a nurses' conference organized by the Federal Institute for Health Protection in Belgrade was held and was attended by nurses from the Pneumophthisiology Section with three lectures. The third professional conference was held in 1976 [4].

The fourth professional conference was held in 1977, and the fifth in 1978 in Stubičke toplice[5]. That year, the nurses 
U Sarajevu je 8. - 11. svibnja 1979. godine održan 1. Kongres medicinskih sestara Pneumoftiziološke sekcije Jugoslavije. Nekoliko zaključaka tog Kongresa potrebno je izdvojiti. Medicinske su sestre utvrdile da je potrebno poboljšati: kontrolirano liječenje u pneumoftiziološkoj službi - osobito se to odnosilo na dispanzere; povećati obuhvat djece BCG vakcinom i to osobito djece rođene kod kuće, te uspostaviti jedinstvenu metodologiju rada u stacionarnim pneumoftiziološkim ustanovama za sve profile medicinskih i nemedicinskih djelatnika [7].

U Stubičkim toplicama održano je 6. (6. - 8. studenog 1979.) i 7. (5. - 7. studenog 1980.) Stručno savjetovanje, a radovi s tih savjetovanja objavljeni su u Biltenu [8]. U Opatiji je 11. 14. listopada 1982. godine u organizaciji Službe za tuberkulozu Saveznog zavoda za zdravstvenu zaštitu iz Beograda održan seminar na kojem su medicinske sestre iz Hrvatske imale tri zapažena rada. Nakon toga, 8. Stručno savjetovanje održano je 3. - 5. studenog 1981. godine. Glavna tema bila je uloga medicinske sestre u pneumoftiziološkoj službi. Bilo je prezentirano ukupno 13 stručnih radova [9].

9. Savjetovanje održano je 1982. godine s temom Medicinske sestre u pneumoftiziološkoj praksi. Drugi Kongres Pneumoftiziološke sekcije medicinskih sestara Jugoslavije održan je u Portorožu 10. - 12. lipnja 1984. U sklopu Kongresa medicinske sestre iz Hrvatske organizirale su sesiju na kojoj je tema bila njega i edukacija plućnih bolesnika u bolničkim ustanovama. U Stubičkim toplicama Pneumoftiziološka sekcija održala je svoje 10. i 11. Stručno savjetovanje [10].

U periodu između 1983. i 1984. godine organizirano je 6 različitih seminara za medicinske sestre u svrhu edukacije i usavršavanja. Sljedeće, 12. Stručno savjetovanje održano je u Lipiku 7. - 10. studenog 1985.godine. Bilo je prisutno 96 medicinskih sestara. Slijedi 13. Stručno savjetovanje koje je održano 23. - 25. listopada 1986. u Osijeku, a glavna tema bila je organizacija rada sestrinske službe te intrahospitalne infekcije. Između 1985. i 1986. održano je 9 stručnih seminara s temama: primjena lijekova u pulmologiji, sarkoidoza, etika zdravstvenih radnika. Stručni posjet Kliničkom bolničkom centru u Ljubljani organiziran je 1985. godine [11].

U vrijeme Domovinskog rata, 90-ih godina, nastavlja se sa stručnim radom te se organiziraju stručni skupovi u Klinici za plućne bolesti Jordanovac. Tijekom 1996. godine održano je 25. Pulmološko savjetovanje u Topuskom na temu Kontinuirane zdravstvene njege bolesnika [12]. Povodom Dana sestrinstva 1998. godine organizirana je Proljetna pulmološka radionica u Klinici za plućne bolesti Jordanovac. Iste godine u Slavonskom Brodu organizirano je 26. Pulmološko savjetovanje s temama: Jesmo li bitku s TBC dobili ili izgubili i Hitna stanja u pulmologiji [13].

Godine 2000. organizirana je u Zagrebu radionica Dišni sustav - anatomija, fiziologija, patofiziologija za medicinske sestre. Iste je godine snimljen prvi edukacijski film za bolesnike Bronhoskopija nije bauk, kao priprema bolesnika za bronhoskopiju [14].

Pulmološka sekcija 2001. godine započinje diskusije o holističkom pristupu bolesniku, među prvima u Hrvatskoj. U Opatiji se 2001. godine organizira 28. Pulmološki simpozij na temu Cjeloviti pristup pulmološkom bolesniku [15]. of the Pneumophthysiology Section became actively involved in the discussion about the Bill on Health Protection, with special emphasis on the impossibility of further training and education of nurses. In 1979, the Pneumophthisiology Section supported and assisted in the establishment of a related section of Serbian nurses.[6].

In Sarajevo on 8-11 May 1979, the 1st Congress of Nurses of the Pneumophthisiology Section of Yugoslavia was held. Some of the conclusion of this congress need to be emphasized. Nurses stated that following improvements were needed: improving control of treatment in the pneumophthisiological service - especially in health centers; improvement of coverage of children with the BCG vaccine, especially for children born at home, establishing a unique methodology for work in inpatient pneumophthisiological institutions for all profiles of medical and non-medical professionals [7].

In Stubičke toplice the sixth (6-8 November 1979) and seventh (5-7 November 1980) professional conferences were held, with papers from these conferences published in the Bulletin [8]. On 11-14 October 1982, a seminar was organized in Opatija by the Tuberculosis Service of the Federal Institute of Public Health in Belgrade. There nurses from Croatia presented three important papers. The eighth professional conference was held 3-5 November 1981. The main topic was the role of the nurse in the pneumophthisiological service. Thirteen professional papers were presented [9].

The ninth conference was held in 1982 with the topic: Nurses in pneumophthisiological practice. The 2nd Congress of the Pneumophthisiology Section of Nurses of Yugoslavia was held in Portorož on 10-12 June 1984. As part of the Congress, nurses from Croatia organized a session about the care and education of lung patients in hospital institutions. In Stubičke toplice the Pneumophthisiology Section held its 10th and 11th professional conference [10].

Between 1983 and 1984, six different nurse seminars were organized for the purpose of education and training. The 12th professional conference was held in Lipik on 7-10 November 1985, attended by ninety-six nurses. The 13th professional conference was held on 23-25 October 1986 in Osijek, with the main topic being the organization of nursing work and combating hospital infections. Between 1985 and 1986, a total of nine professional seminars was held on the following topics: drug application in pulmonology, sarcoidosis, ethics of health professionals. In 1985 a professional visit was organized to the University hospital center Ljubljana [11].

During the 1990s, during the Croatian war of independence, professional work continued, and professional conferences were organized at the Jordanovac Clinic for Lung Diseases. In 1996, the 25th Pulmonological conference was held in Topusko on the topic Continuing patient health care [12]. On the occasion of the International Nurse Day in 1998 the Spring Pulmonary Workshop was organized at the Jordanovac Clinic for Lung Diseases. In Slavonski Brod in the same year the 26th Pulmonological conference was held covering these topics: Have we won or lost the battle with TB and Emergencies in pulmonology [13].

In 2000, in Zagreb a workshop was organized: Respiratory system - anatomy, physiology, and pathophysiology for nur- 
Prvi Pulmološki kongres održan je u Zagrebu 2003. na temu Kontinuirano poboljšanje kvalitete rada. lako je tadašnji Upravni odbor HUMS-a kongres zabranio, kongres je ipak održan. Prvi put na Kongresu se govori o informatizaciji u sestrinstvu, a umjesto tiskanih materijala, sudionici dobivaju sve materijale na CD-u [16].

U 2004. godini organiziran je 29. Stručni skup u Bolnici Klenovnik s temom Tuberkuloza, Komunikacija - iskustvo sestara, a godine 2005. organizira se u Crikvenici 30. Pulmološki stručni skup na temu Zdravstvena njega bolesnika s karcinomom pluća; Prevencija pogoršanja opstruktivne bolesti pluća [17]. Pulmološko društvo 2006. godine aktivno sudjeluje na Kongresu HUMS-a s temom Individualna edukacija bolesnika oboljelog od tuberkuloze pluća [18]. U Klenovniku se 2007. godine organizira 31. Pulmološki stručni skup s temom $\mathrm{Ne}$ pušenje je in [19]. Iduće godine u Zagrebu tema 32. Stručnog skupa je Sestrinska dokumentacija u pulmologiji [20].

Tijekom 2009. godine organizira se 33. Pulmološki stručni skup s temama Holistički pristup bolesniku oboljelom od karcinoma pluća i Inhalacijska terapija [21]. U ožujku 2010. godine Pulmološko društvo aktivno sudjeluje na petom Kongresu HUMS-a zajedno s ostalim stručnim društvima s temom Okruženje pozitivne prakse. Na skupu su prezentirane teme koje su u fokusu imale kvalitetu radnog mjesta, sigurnost na radnom mjestu, stres i zadovoljstvo poslom [22].

Stručni skup održan 2011. godine u Opatiji ističe važnost kvalitetne komunikacije između medicinske sestre i pulmološkog bolesnika s posebnim osvrtom na komunikaciju s bolesnicima na mehaničkoj ventilaciji, te traheotomiranim bolesnicima [23].

U Trakošćanu se 2012. godine održava stručni skup radnog naslova Novosti u pulmologiji [24]. Trideset i sedmi Stručni skup održan je u Samoboru 2013. godine i prati temu Komorbiditet pulmološkog bolesnika [25]. Sljedeće godine u Zagrebu organizira se 38 . Stručni skup na kojem se prezentiraju radovi na temu Sestrinske dijagnoze u pulmologiji. Tema prati tadašnja aktualna nastojanja koja sestrinske dijagnoze i njihovu primjenu vide kao ključ za uspješnu, utemeljenu na dokazima i profesionalno vođenu zdravstvenu njegu, čiji je cilj da što kvalitetnije zadovolji potrebe bolesnika [26]. Godine 2015. organizira se 39. Stručni

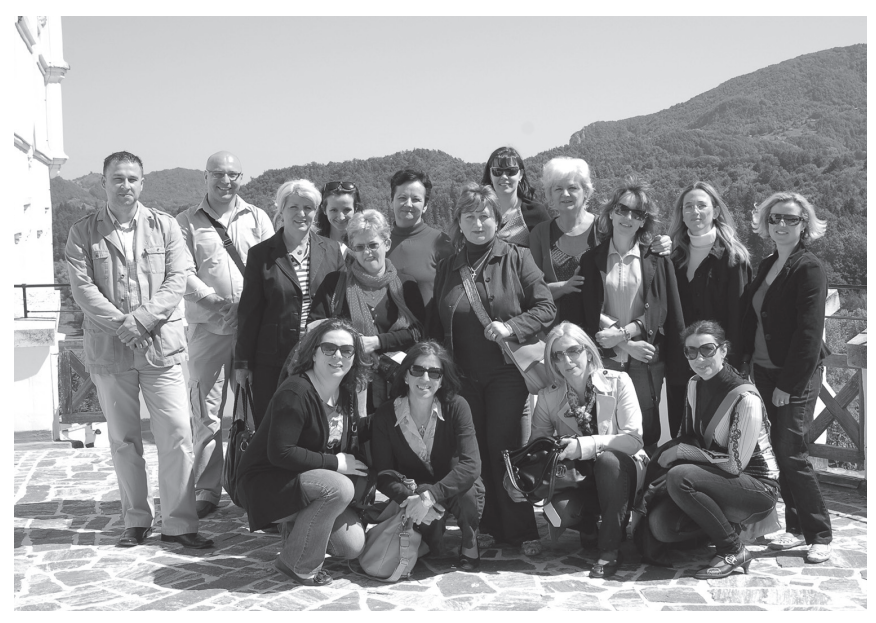

Slika/Fıgure 1. Sudionici 36. stručnog skupa Pulmološkog društva HUMS-a, Trakošćan 2012 / Participants of the $36^{\text {th }}$ professional meeting of the Pulmonology Society of CMA, Trakošćan 2012 ses. In the same year the first educational film for patients was made, under the title Bronchoscopy is not a nightmare. Its purpose was to prepare patients for bronchoscopy[14].

In 2001, among the first in Croatia the Pulmonology Section began discussions about an integrated approach to the patient. In Opatija in 2001 the 28th Pulmonological conference was held with the topic A holistic approach to the pulmonary patient[15]. The first Pulmonological congress was held in Zagreb in 2003 with the topic Continuing improvement of qualitative care. Although the congress was banned by the then Governing Board of the CNA, the congress was held, nevertheless. For the first time on a Congress, informatization in nursing is discussed, and instead of printed materials, participants receive all the materials on CD [16].

In 2004 the 29th Professional conference was held in the Klenovnik hospital with the topic Tuberculosis, communication - nurse experiences, and in 2005 in Crikvenica the 30th Pulmonological conference was held on the topic of Nursing care for patients with lung cancer; Prevention of exacerbations in obstructive pulmonary disease[17]. The pulmonology society took active part in the 2006 Congress of the CNA on the topic of Individual education of patients with TB [18]. In Klenovnik, in 2007 the 31st Pulmonological conference was organized with the topic Non-smoking is fashionable [19]. Next year in Zagreb the topic of the 32nd professional conference was Nursing records in pulmonology [20].

During 2009 the 33rd Pulmonological conference was held covering the topics Holistic approach to a patient with lung cancer and Inhalation therapy[21]. In March 2010 the pulmonology society actively participated in the fifth Congress of the CNA, together with other professional societies with the topic Safe work environment. Presented topics focused on the quality of the workplace, safety in the workplace, stress and job satisfaction.[22].

The conference held in 2011 in Opatija emphasized the importance of good communication between the nurse and the pulmonary patient with special emphasis on communication with patients on mechanical ventilation and tracheotomized patients[23].

In 2012, a conference with the working title Innovations in Pulmonology was held in Trakošćan [24]. The topic of the thirty-seventh conference held in Samobor in 2013 was Comorbidities in pulmonary patients[25]. Next year the 38th conference was held in Zagreb, presenting papers on the topic of Nursing diagnoses in pulmonology. The topic followed the increasingly current efforts that consider nursing diagnoses and their application as key to a successful, evidence-based and professionally guided health service, whose goal it is to better meet the needs of patients [26]. In 2015, the 39th conference was held on the topic of Oxygen therapy at home. On the conference the handbook for patients and health workers Oxygen application at home was presented [27]. The 40th jubilee professional meeting was held in 2017 in Klenovnik on the topic of Palliative Care and Rehabilitation in Pulmonology. Emphasis was put on the specifics of patient care in the chronic or terminal phase of lung disease [28]. 
skup s temom Terapija kisikom u kućnim uvjetima. Na stručnom skupu održana je i promocija priručnika za bolesnike i zdravstvene djelatnike Liječenje kisikom u kući [27]. Jubilarni 40. Stručni skup održan je 2017. godine u Klenovniku na temu Palijativna skrb i rehabilitacija u pulmologiji. Naglasak je stavljen na specifičnosti zbrinjavanja plućnih bolesnika u kroničnoj i terminalnoj fazi plućne bolesti [28].

Organizacija 41. Stručnog skupa 2018. godine na temu Neinvazivna mehanička ventilacija bila je otežana zbog financijskih teškoća te se odgađa za 2019. godinu kada je skup uspješno održan u Klenovniku. Ondje je istaknuto korištenje neinvazivne mehaničke ventilacije u bolničkim i kućnim uvjetima, komplikacije neinvazivne mehaničke ventilacije, te provođenje fizioterapije kod bolesnika na neinvazivnoj mehaničkoj ventilaciji [29]. Krajem 2017. godine Pulmološko društvo obilježilo je Svjetski dan kronične opstruktivne bolesti pluća organiziranom javnozdravstvenom akcijom u parku Maksimir [30]. U proljeće 2018. godine obilježilo je Svjetski dan borbe protiv tuberkuloze nizom predavanja za zdravstvene djelatnike održanima u Zagrebu [31].

Tijekom 2020. godine zbog izbijanja pandemije COVID-19 infekcije, 42. Stručni skup nije održan. U 2021. godini Pulmološko društvo sudjeluje na 9. Kongresu HUMS-a s posterom na temu Stres kod zdravstvenih djelatnika za vrijeme pandemije COVID-19 infekcije za koji dobivaju nagradu za najbolji poster [32].

\section{Bilten Pneumoftiziološke sekcije Društva medicinskih sestara i tehničara SRH}

Bilten je bio publikacija Pneumoftiziološke sekcije Društva medicinskih sestara i medicinskih tehničara SR Hrvatske. Pokrenut je 1975. godine i izlazi do 1989. godine. Publicirana su 23 broja. Učestalost izlaženja ovisila je o tehničkim i materijalnim mogućnostima, a Bilten je bio besplatan. Članke za Bilten pisale su: medicinske sestre, liječnici (pulmolozi, mikrobiolozi, anesteziolozi, citolozi) fizioterapeuti, laboratorijski tehničari, rendgen tehničari, dijetetičari i psiholozi [33].

Objavljeni članci uglavnom su bili stručni članci, ali nalazimo i članke u kojima su prikazani rezultati istraživanja. Prikazana istraživanja provedena su korištenjem upitnika ili retrospektivnim pregledom medicinske dokumentacije.

U Biltenu se pisalo o različitim temama iz područja pneumoftiziologije i pulmologije prateći promjene u tim područjima. Osnovni je cilj bio omogućiti medicinskim sestrama stručnu literaturu. Velik trud i entuzijazam uložen je u svaki broj. Prilozi su pisani na mašini, a crteži i tablice koji se nalaze u pojedinim brojevima Biltena crtani su rukom.

Tema o kojoj se pisalo obrađivala se s različitih aspekata. Poneki brojevi bili su tematski i pisalo se o tuberkulozi pluća, karcinomu bronha, hospitalnim infekcijama, plućnim problemima u djece i procesu zdravstvene njege.

U većini brojeva na samom kraju nalazili su se zapisnici sa sastanaka Pneumoftiziološke sekcije, plan rada, izvješća s godišnjih skupština i izvješća s kongresa.

Urednici Biltena bili su: Stana Lovrić, 1975. - 1978. (broj 1 do broja 8); Marko Čurlin, 1979. - 1981. (broj 9 do broja 13
The organization of the 41st conference in 2018 with the topic Non-invasive mechanical ventilation was prevented by financial difficulties and was therefore postponed for 2019 when it was successfully held in Klenovnik. Emphasis was placed on the use of non-invasive mechanical ventilation in hospital and home conditions, complications of noninvasive mechanical ventilation, and the implementation of physiotherapy in patients with non-invasive mechanical ventilation.[29]. In late 2017, the pulmonology society marked the World COPD Day with an organized public health activity in Zagreb's Maksimir Park [30]. In the Spring of 2018, it marked the World Tuberculosis Day with a series of lectures for health professionals, held in Zagreb [31].

During 2020, the 42nd conference was cancelled due to the Covid-19 pandemic. In 2021 the Pulmonology society took part in the 9th Congress of the CNA with a poster covering the topic of Stress in health professionals during the Covid-19 pandemic, for which it was awarded the prize for best poster [32].

\section{The Bulletin of the Pneumophthisiology section of the Society of Nurses of the Socialist Republic of Croatia}

The "Bulletin" was a publication of the Pneumophthisiology section of the Society of Nurses of the Socialist Republic of Croatia. Its publication began in 1975 and lasted until 1989. Twenty-three issues were published. The frequency of publication depended on technical and material abilities, and the bulletin was available free of charge. The articles in the Bulletin were written by nurses, physicians (pulmonologists, microbiologists, anesthesiologists, cytologists), physiotherapists, laboratory technicians, X-ray technicians, dieticians and psychologists [33].

The published articles were mostly expert articles, but there were also articles that presented research results. The presented research was conducted using questionnaires or retrospective reviews of medical records.

The Bulletin covered various topics in the field of pneumophthisiology and pulmonology, closely following changes in these fields. The main goal was to provide nurses with professional literature. Great effort and enthusiasm were invested in each issue. The articles were typed on a typewriter, while the drawings and tables in some issues of the Bulletin were drawn by hand.

The topics were covered from different aspects. Some issues of the bulletin were themed, covering pulmonary tuberculosis or bronchial cancer, nosocomial infections, lung problems in children, or the nursing process.

Most of the issues contained minutes from the meetings of the Pneumophthisiology Section, a plan of activities, reports from the annual assemblies and reports from the conference.

Editors of the Bulletin were: Stana Lovrić 1975 - 1978 (issue 1 to issue 8); Marko Čurlin 1979 - 1981 (issue 9 to issue 13 ); Marija Havetić 1982 - 1984 (issue 14 to issue 17 ); Renata Šimonić 1985 - 1986 (issue 18 to issue 20 ); Milka Valpotić 1987 - 1989 (issue 21 to issue 23 ) [33]. 
); Marija Havetić, 1982. - 1984. (broj 14 do broja 17 ); Renata Šimonić, 1985. - 1986. (broj 18 do broja 20 ); Milka Valpotić, 1987. - 1989. (broj 21 do broja 23 ) [33].

Članci su pisani u formi referata bez današnje uobičajene strukture i tek je rijetko bila navedena literatura. Najveći broj članaka obrađivao je teme usmjerene na medicinsku dijagnozu s navedenim sestrinskim postupcima, obrade sestrinskih postupaka te prikaze istraživanja u kojima je korišten anketni upitnik. Najviše radova pisao je jedan autor. Za vrijeme u kojem su objavljeni, članci su predstavljali vrijednu stručnu literaturu medicinskim sestrama koje su skrbile za bolesnike oboljele od plućnih bolesti. Dodatno je hvalevrijedan napor oko njegova objavljivanja jer je u vrijeme izlaženja sestrinska stručna literatura na hrvatskom jeziku bila rijetkost.
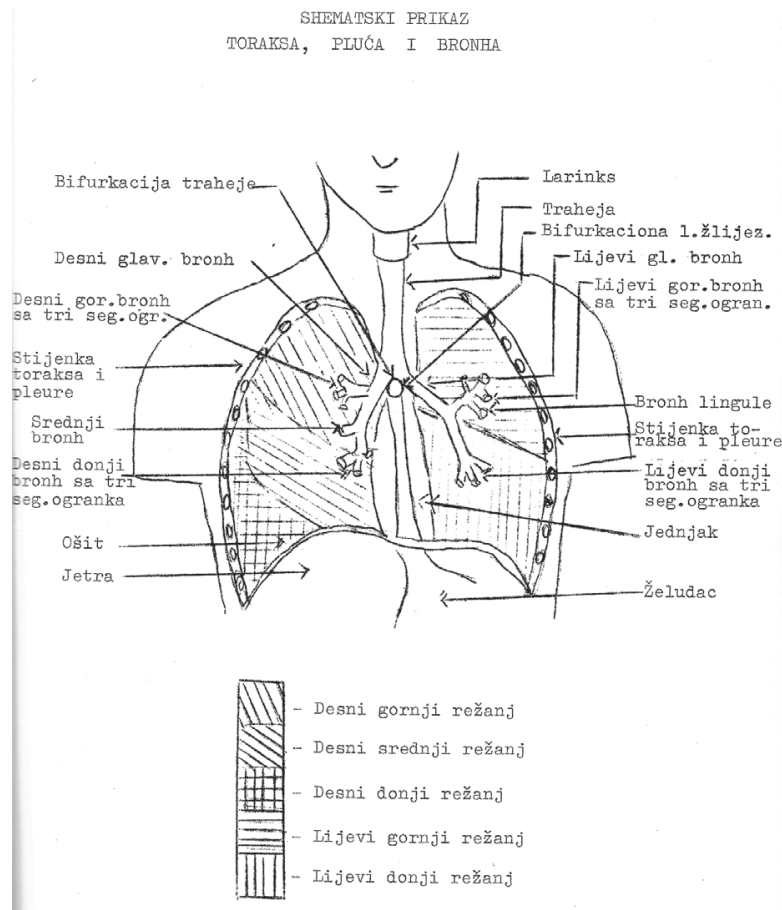

SLIKA/FIGURE 2. Izvadak iz prvog broja Biltena / Excerpt from the first issue of the Bulletin

\section{Publikacije članova Pulmološkog društva HUMS-a}

Osim Biltena, medicinske sestre Pulmološke sekcije publicirale su nekoliko izuzetno vrijednih materijala. Godine 1999. izdan je priručnik Kako živjeti s astmom autorice Rosane Svetić Čišić. To je prvi takav priručnik koji na jednostavan način opisuje što se događa s tijelom kada imamo astmu i kako si oboljeli može pomoći. Na jednak način bio je vrijedan edukativni materijal osobama oboljelima od astme i medicinskim sestrama [34].

Grupa autora 2000. godine izdaje Osnovne smjernice za postupke i zdravstvenu njegu u pulmologiji. Priručnik je podijeIjen na nekoliko poglavlja: postupci u dijagnostici pulmologije; inhalacijska terapija; mehanička ventilacija; urgentna stanja u pulmologiji i kronična stanja u pulmologiji. Bio je to početak standardizacije postupaka kojemu je cilj bio osi-
Articles were written in the form of reports, without the structure that is usual nowadays, and only rarely with any cited literature. Most of the articles dealt with topics focused on medical diagnoses and the related nursing procedures, processing of nursing procedures and presentations of research in which questionnaires were used. Most papers were written by a single author. At the time, the published articles were valuable professional literature for nurses taking care of patients with lung disease. The effort put in the publication of the Bulletin is remarkable, because at the time of its publication, nursing professional literature in the Croatian language was a rarity.

\section{Publications by members of the Pulmonology Society of the CNA}

Apart from the Bulletin, nurses from the Pulmonology society published several very useful materials. In 1999, the manual How to live with asthma by Rosana Svetić Čišić was published. This is the first manual of its kind that in simple terms described what happens to the body when we have asthma and how patients can help themselves. As educational material, it was valuable to patients with asthma as well as to nurses[34].

In 2000, a group of authors published Basic guidelines for procedures and nursing care in pulmonology. The manual is divided into several chapters: diagnoses procedures in pulmonology; inhalation therapy; mechanical ventilation; emergencies in pulmonology and chronic conditions in pulmonology. This marked the beginning of procedure standardization with the goal of achieving uniformity of nurse work in pulmonology [35].

The handbook Inhalation therapy by Rosana Svetić Čišić and Zorana Jurković was published in 2007 and enabled a systematic review of inhalation therapy application past and present. The handbook was written mostly for nurses as educational material [36].

In 2015, Tatjana Munko, Nataša Skelin Uglik and Martina Komerički published the handbook Oxygen therapy at home. The handbook was designed as educational material for health professionals and patients in order to improve the quality of life of people who use oxygen therapy at home [37].

\section{Prizes and recognitions awarded to the Pneumophthisiology Section/Pulmonology Society of the CNA}

At the first congress of the Pneumophthisiology section of Nurses of Yugoslavia held in 1979 in Sarajevo, nurse Aleksandra Tilli from Croatia received an honorary diploma for merits and contribution for her work with tuberculosis patients. At the same congress, diplomas for assistance in organizing the congress were awarded to: Katarina Krvavica, Blanka Trajkovski and Stana Lovrić [4].

On 23 November 1979, the 50th anniversary of the founding of the Nurses' society of the Socialist Republic of Croatia was marked in Zagreb, and on that occasion the Pne- 
gurati ujednačenost rada medicinskih sestara i tehničara u pulmologiji [35].

Priručnik Inhalacijska terapija autorica Rosane Svetić Čišić i Zorane Jurković izdan 2007. godine omogućio je sustavan pregled primjene inhalacijske terapije tijekom povijesti sve do danas. Priručnik je prvenstveno namijenjen medicinskim sestrama kao edukativni materijal [36].

Tatjana Munko, Nataša Skelin Uglik i Martina Komerički objavile su 2015. godine priručnik Liječenje kisikom u kući. Priručnik je osmišljen kao edukativni materijal za zdravstvene djelatnike i za pacijente u cilju podizanja kvalitete života osoba koje liječenje kisikom koriste u kućnim uvjetima [37].

\section{Nagrade, priznanja Pneumoftiziološke sekcije / Pulmološkog društva HUMS-a}

Na prvom Kongresu Pneumoftiziološke sekcije medicinskih sestara i tehničara Jugoslavije održanom 1979. u Sarajevu, počasnu diplomu dobila je medicinska sestra Aleksandra Tilli iz Hrvatske za zasluge i doprinos u radu s tuberkuloznim bolesnicima. Na istom Kongresu povelje za pomoć u organizaciji dobile su: Katarina Krvavica, Blanka Trajkovski i Stana Lovrić [4].

U Zagrebu je 23. studenog 1979. obilježena 50. godišnjica osnutka Društva medicinskih sestara SRH te je tom prigodom Pneumoftiziološkoj sekciji dodijeljena pismena zahvalnica za postignute uspjehe u petogodišnjem radu [7].

Crveni je križ u Hrvatskoj povodom 100. godišnjice otkrića bacila tuberkuloze 1982. godine dodijelio Pneumoftiziološkoj sekciji zahvalnicu za suradnju i doprinos u suzbijanju tuberkuloze. Ivan Božić u ime Izvršnog odbora sekcije dao je prijedlog da se izradi plaketa sekcije te jednom godišnje dodjeljuje zaslužnim pojedincima ili/i ustanovama za razvoj sestrinske službe u pulmologiji. Taj je prijedlog prihvaćen, plaketa je izrađena i dodjeljivana je jednom godišnje do početka Domovinskog rata [9].

Na drugom Kongresu Pneumoftiziološke sekcije medicinskih sestara Jugoslavije u Portorožu 1984. godine priznanja za rad dobile su: Katarina Krvavica, Stana Lovrić, Blanka Trajkovski, Katarina Sever, Ivan Božić, Marija Mautner, Marija Havetić, Đurđa Gec, Vesna Prišlin, Rajka Bilić, Vesna Radović, Ljiljana Gerliza, Marinka Mirković i Milica Ostorovidov. Tom prigodom dodijeljeno je i priznanje Pneumoftiziološkoj sekciji Hrvatske za uspješan dugogodišnji rad [10].

\section{Zaključak}

Pulmološko društvo HUMS-a postoji 47 godina. Od osnutka do danas najvažnija mu je svrha bila pružiti i omogućiti edukaciju medicinskim sestrama u pulmologiji kako bi pružile što bolju skrb pacijentima. U 47 godina Pulmološko društvo organiziralo je 42 stručna savjetovanja, mnoštvo stručnih seminara i surađivalo je s drugih stručnim društvima. Također, velik doprinos dalo je u publiciranju stručne literature, najprije putem svog Biltena kao stručnog glasila Pneumoftiziološke sekcije, a kasnije putem priručnika za medicinske sestre.

Dugogodišnja tradicija i iskustvo i dalje inspiriraju članove Pulmološkog društva te su u pripremi skupovi s međuna- umophthisiology Section was awarded a written letter of acknowledgement for the successes achieved in its five years of activity [7].

In 1982, on the occasion of the 100th anniversary of the discovery of the tuberculosis bacillus, the Red Cros of Croatia awarded the Pneumophthisiology Section a letter of acknowledgement for its cooperation and contribution in the fight against tuberculosis. Ivan Božić made a proposal on behalf of the Executive Board of the Section to create a section plaque and award it once a year to deserving individuals and / or institutions, who helped in the development of nursing in pulmonology. This proposal was accepted, and a plaque was made and afterwards awarded once a year until the beginning of the Croatian war of independence [9].

In 1984, on the 2nd Congress of the Pneumophthisiology section of nurses of Yugoslavia in Portorož, diplomas were awarded to: Katarina Krvavica, Stana Lovrić, Blanka Trajkovski, Katarina Sever, Ivan Božić, Marija Mautner, Marija Havetić, Đurđa Gec, Vesna Prišlin, Rajka Bilić, Vesna Radović, Ljiljana Gerliza, Marinka Mirković and Milica Ostorovidov. On that occasion, the Pneumophthisiology Section of Croatia was awarded a diploma for its successful long-term activity [10].

\section{Conclusion}

The Pulmonology Society of the CNA has been active for 47 years. Since its founding, the society's most important purpose was to provide and facilitate education for nurses in pulmonology and thus enable them to provide better nursing care. During its 47 years of activity, the Pulmonology society organized forty-two professional conferences, countless professional seminars, and cooperation with other professional societies. The society made a great contribution to the publication of professional literature, first through the Bulletin as a professional journal of the Pneumophthisiology Section, and later through manuals for nurses.

Many years of tradition and experience continue to inspire members of the Pulmonology Society; meetings with international participation and the preparation of publications for the purpose of educating patients and health professionals are in the works.

The members of the Society foster respect for their predecessors and teachers, but they also open up opportunities for young colleagues to act not only in an environment that promotes the nursing profession but also in an environment that nurtures the core values of cooperation and respect. 
rodnim sudjelovanjem i izrada publikacije u svrhu edukacije bolesnika i zdravstvenih djelatnika.

Članovi Društva njeguju poštovanje prema svojim prethodnicima i učiteljima, ali jednako tako otvaraju prilike mladim kolegama koji imaju mogućnost djelovanja ne samo u okruženju koje unapređuje sestrinsku profesiju već i u okruženju koje njeguje osnovne vrijednosti sestrinstva orijentiranog na suradnju i poštovanje.

\section{Zahvala}

Ovaj članak nastao je na inicijativu jedne posebne osobe - Sande Franković. Iskrena zahvala za utrošeno vrijeme, savjete, podršku, entuzijazam i ustrajnost da ovaj članak bude napisan i objavljen. Vi imate viziju i hvala Vam što je mogu dijeliti s Vama.

\section{Nema sukoba interesa}

\section{Literatura}

[1] Zapisnik Osnivačke skupštine Pneumoftiziološke sekcije Društva medicinskih sestara i medicinskih tehničara Hrvatske. Bilten Pneumoftiziološke sekcije Saveza društava medicinskih sestara SR Hrvatske. 1975; 1:57-67.

[2] Lovrić S. Prvi put na kongresu. Bilten Pneumoftiziološke sekcije Saveza društava medicinskih sestara SR Hrvatske. 1975; 2:3-7.

[3] Lovrić S. (ur.). Bilten Pneumoftiziološke sekcije Saveza društava medicinskih sestara SR Hrvatske. 1976; 3: 88-95.

[4] Krvavica K. Izvještaj o radu Pneumoftiziološke sekcije Društva medicinskih sestara i tehničara SR Hrvatske. Bilten Pneumoftiziološke sekcije Saveza društava medicinskih sestara SR Hrvatske. 1977; 5: 73-81.

[5] Trajkovski B. Izvještaj o radu Pneumoftiziološke sekcije Društva medicinskih sestara i tehničara SR Hrvatske. Bilten Pneumoftiziološke sekcije Saveza društava medicinskih sestara SR Hrvatske. 1979; 9: 61-74.

[6] Program rada za 1979.godinu. Bilten Pneumoftiziološke sekcije Saveza društava medicinskih sestara SR Hrvatske. 1979; 10: 58-66.

[7] Zaključci 1. Kongresa Pneumoftiziološkh sestara i tehničara Jugoslavije. Bilten Pneumoftiziološke sekcije Saveza društava medicinskih sestara SR Hrvatske. 1980; 11 - 12: 98-103.

[8] Havetić M. Godišnja skupština sekcije. Bilten Pneumoftiziološke sekcije Saveza društava medicinskih sestara SR Hrvatske. 1981; 13: 72-6.

[9] Bauk K. Izvještaj s godišnje skupštine. Bilten Pneumoftiziološke sekcije Saveza društava medicinskih sestara SR Hrvatske. 1982; 14: 35-43.

[10] Fučkar G. Osvrt na 2. Kongres Pneumoftiziološke sekcije medicinskih sestara i tehničara Jugoslavije. Bilten Pneumoftiziološke sekcije Saveza društava medicinskih sestara SR Hrvatske. 1984; 15-16:5-13.

[11] Bauk K, Fučkar G. Izvještaj o radu sekcije u mandatnom razdoblju 1982. - 1984. Bilten Pneumoftiziološke sekcije Saveza društava medicinskih sestara SR Hrvatske. 1985; 19: 65-76.

[12] 25. Pulmološko savjetovanje medicinskih sestara. Pismohrana Pulmološkog društva HUMS-a. 1996.

[13] 26. Pulmološko savjetovanje medicinskih sestara. Pismohrana Pulmološkog društva HUMS-a. 1998.

[14] Jurković Z, Svetić Čišić R. Dišni sustav - anatomija, fiziologija, patofiziologija. Skripta za medicinske sestre. Zagreb. HUMS; 1999.

[15] 28. Pulmološki simpozij medicinskih sestara. Pismohrana Pulmološkog društva HUMS-a. 2001.

[16] 1. Pulmološki kongres medicinskih sestara. Pismohrana Pulmološkog društva HUMS-a. 2003.

[17] 29. Pulmološki stručni skup medicinskih sestara. Pismohrana Pulmološkog društva HUMS-a. 2005.

[18] 3. Kongres HUMS-a. Pismohrana HUMS-a. 2006.

[19] 31. Pulmološki stručni skup medicinskih sestara. Pismohrana Pulmološkog društva HUMS-a. 2007.

\section{Acknowledgements}

The writing of this article was initiated by a very special person - Sanda Franković. We sincerely thank you for your time, advice, support, enthusiasm, and perseverance that made the writing and publication of this article possible. You are a visionary and we are thankful for being able to share in your vision.

\section{Authors declare no conflict of interest}

[20] 32. Pulmološki stručni skup medicinskih sestara. Pismohrana Pulmološkog društva HUMS-a. 2008.

[21] 33. Pulmološki stručni skup medicinskih sestara. Pismohrana Pulmološkog društva HUMS-a. 2009.

[22] 5. Kongres HUMS-a. Pismohrana HUMS-a. 2010.

[23] Golubić R., Fištrek M. Važnost kvalitetene komunikacije medicinskih sestara s pulmološkim bolesnikom. 35. Stručni skup Pulmološkog društva HUMS-a, Opatija, 18. - 19. ožujka 2011. Sestrinski glasnik. 2011; 16: 125-6.

[24] 36. Pulmološki stručni skup medicinskih sestara. Pismohrana Pulmološkog društva HUMS-a. 2012.

[25] Režić S. Fištrek M. 37. stručni skup "Komorbiditet plućnih bolesnika”, Pulmološko društvo- Hrvatska udruga medicinskih sestara [HUMS], [Samobor 15. 3. 2013.]Sestrinski glasnik. 2013; 18: 149-50.

[26] 38. Pulmološki stručni skup medicinskih sestara. Pismohrana Pulmološkog društva HUMS-a. 2014.

[27] Munko T., Fištrek M. 39. Stručni skup "Liječenje kisikom u kući" Pulmološkog društva HUMS-a. Zagreb. Sestrinski glasnik. 2016; 21: 211-2.

[28] 40. stručni skup Pulmološkog društva HUMS-a - Hrvatska udruga medicinskih sestara dostupno: https://hums.hr/40-strucni-skup-pulmoloskog-drustva-hums-a/, pristupljeno: 24. 9. 2021.

[29] 41. Stručni skup Pulmološkog stručnog društva HUMS-a. dostupno na: https://view.officeapps.live.com/op/view.aspx? src=https \%3A\%2F\%2Fhums.hr\%2Fwp-content\%2Fuploads\%2Fdruga-obavijest-2017-1.doc\&wdOrigin=BROWSELINK , pristupljeno 24. 9. 2021.

[30] Pulmološko društvo HUMS-a - Svjetski dan KOPB-a. Dostupno na: https://hums.hr/wp-content/uploads/Plakat-Zdrava-pluca.pdf , pristupljeno 20.10.2021.

[31] Pulmološko društvo HUMS-a - Svjetski dan borbe protiv tuberkuloze. Dostupno na: https://hums.hr/wp-content/uploads/Tuberculosisday.pdf, pristupljeno: 20. 10. 2021.

[32] 9. Kongres Hrvatske udruge medicinskih sestara. Dostupno na: https://hums.hr/objavljen-je-program-9-kongresa-hrvatske-udrugemedicinskih-sestara/ pristupljeno: 24. 9. 2021.

[33] Valpotić M. Izvještaj s godišnje skupštine. Bilten Pneumoftiziološke sekcije Saveza društava medicinskih sestara SR Hrvatske. 1989; 23: 35-43.

[34] Svetić Čišić R. Kako živjeti s astmom. Zagreb: Medicinska naklada; 1999.

[35] Osnovne smjernice za postupke i zdravstvenu njegu u pulmologiji. Zagreb:HUMS; 2000.

[36] Svetić-Čišić R, Jurković Z. Inhalacijska terapija. Zagreb: HUMS; 2007.

[37] Munko T, Skelin Uglik N, Komerečki M. Liječenje kisikom u kući. Zagreb: vlastita naklada; 2015. 